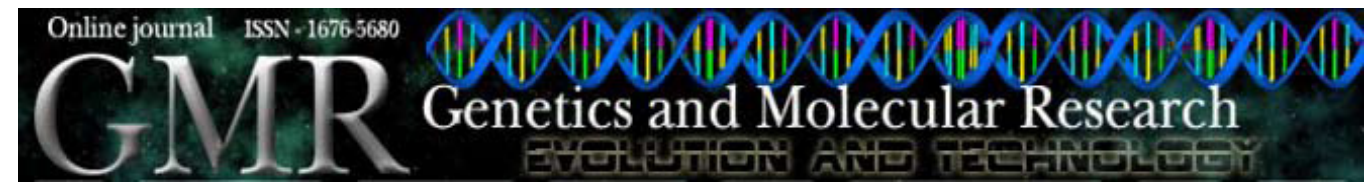

\title{
Transferability of microsatellite loci from exotic Cervidae to Brazilian brocket deer (Mazama spp, Mammalia: Cervidae)
}

\author{
A.M.B. Mantellatto, E.A.G. Carnelossi and J.M.B. Duarte \\ Departamento de Zootecnia, Núcleo de Pesquisa e Conservação de Cervídeos, \\ Faculdade de Ciências Agrárias e Veterinárias de Jaboticabal, \\ Universidade Estadual Paulista, Jaboticabal, SP, Brasil \\ Corresponding author: A.M.B. Mantellatto \\ E-mail: alinemeira22@hotmail.com
}

Genet. Mol. Res. 9 (1): 277-282 (2010)

Received October 26, 2009

Accepted November 11, 2009

Published February 18, 2010

\begin{abstract}
Transferability of microsatellite loci between closely related species has been reported in several species. This helps reduce costs involved with the development of primers for newly investigated species. Fifteen microsatellite primers developed for Rangifer tarandus, Cervus elaphus, C. axis, and Moschus berezovskii were tested on five species of Brazilian brocket deer of the genus Mazama (M. americana, M. bororo, M. gouazoubira, M. nana, and M. nemorivaga). These primers were tested with DNA extracted from blood samples of two individuals of each species obtained from the Núcleo de Pesquisa e Conservação de Cervídeos (NUPECCE) of Universidade Estadual Paulista (UNESP). Fourteen of the 15 primers tested amplified microsatellite regions of all five species of Mazama, confirmed by sequencing of the amplified fragments. We conclude that these primers could be used for population studies of brocket deer.
\end{abstract}

Key words: Microsatellite; Heterologous primers; Brocket deer; Mazama 


\section{INTRODUCTION}

Mazama is the second most numerous genus within the deer of the world (Duarte and Merino, 1997). From cytogenetic (Duarte and Merino, 1997) and morphological (Rossi, 2000) evidence, five species are recognized in Brazil: M. americana, M. bororo, M. gouazoubira, M. nana, and M. nemorivaga. The distribution of the genus extends from southern Mexico to central Argentina, where they occupy various types of habitat such as mountain forests, lowland rain forests and savanna. Mazama occur in almost the entire national territory of Brazil (Eisenberg and Redford, 1999). Illegal hunting and increased destruction of habitat threatens the survival of significant populations of species such as M. nana and M. bororo (IBAMA, 2003; Abril and Duarte, 2008; Duarte, 2008). These conditions usually lead to a decrease in genetic variability due to the absence of gene flow between different populations and due to the effects of genetic drift, which can dramatically reduce the genetic diversity of species (Chesser, 1983), making them more susceptible to environmental changes. Microsatellite loci have been primarily used for the detection of fluctuations in genetic variability. Transferability of microsatellite loci between related species is possible due to the conservation of flanking regions of simple repetitive sequences (Schlötterer and Pemberton, 1994; Rafalski et al., 1996; Ferreira and Grattapaglia, 1996; Zane et al., 2002). This feature allows reduction in labor and costs in the development of primers for each species of interest (Ferreira and Grattapaglia, 1996). Conservation of microsatellite loci between closely related species has been demonstrated in cows, sheep (Moore et al., 1991), primates (Morin and Woodruff, 1992), dogs (Roy et al., 1994), cetaceans (Schlötterer et al., 1991), and turtles (FitzSimmons et al., 1995). The family Cervidae is one of the most studied, by means of microsatellite markers, in the order Artiodactyla. The main factor for this large volume of studies is the extensive number of primers described.

A large number of studies have used primers of mainly bovine origin (Bos sp) (Oliveira, 2005), indicating the conservation of both the flanking regions of the primers and the microsatellite region. Within this context, this study aimed to select heterologous primers for the five Brazilian brocket deer species. We selected 15 microsatellite loci described in the literature for the species Rangifer tarandus (8), Moschus berezovskii (5), Cervus axis (1), and C. elaphus canadensis (1). We obtained a set of microsatellite loci with the potential application for characterization of genetic variability and for population studies in Brazilian species of Mazama.

\section{MATERIAL AND METHODS}

\section{Animals}

Pairs of each species, M. americana, M. bororo, M. gouazoubira, M. nana, and M. nemorivaga, housed at the Núcleo de Pesquisa e Conservação de Cervídeos (NUPECCE) of São Paulo State University (UNESP), were used for this experiment.

\section{DNA extraction and purification}

DNA was extracted from blood cells by digestion with proteinase K, purification with phenol-chloroform and precipitation with absolute ethanol (Sambrook et al., 1989). 


\section{Markers tested}

Fifteen primers were tested (Table 1): 8 developed for $R$. tarandus, 5 for M. berezovskii, 1 for $C$. axis, and 1 for C. elaphus canadensis, selected from the literature with the criteria of close phylogenetic linkage, structure of microsatellite and transferability to other deer species.

\begin{tabular}{|c|c|c|c|c|c|c|}
\hline Primer & Concentration & Repeat motif & Species & Temperature $\left({ }^{\circ} \mathrm{C}\right)$ & Observed size (bp) & Expected size (bp) \\
\hline $\mathrm{CA} 71^{1}$ & $0.1 \mu \mathrm{M}$ & $(\mathrm{CT})_{12}$ & Cervus axis & 58 & $300-310$ & $308-318$ \\
\hline Mber $25 \mathrm{~F}^{2}$ & $1.0 \mu \mathrm{M}$ & $(\mathrm{AC})_{12}$ & Moschus berezovskii & - & - & $166-186$ \\
\hline Mber39B 2 & $1.0 \mu \mathrm{M}$ & $(\mathrm{AC})_{16}$ & Moschus berezovskii & 49 & $180-210$ & $199-235$ \\
\hline Mber43B ${ }^{2}$ & $1.0 \mu \mathrm{M}$ & $(\mathrm{AC})_{20}$ & Moschus berezovskii & 53 & $200-210$ & $204-238$ \\
\hline Mber710B 3 & $15.0 \mu \mathrm{M}$ & $(\mathrm{AC})_{24}$ & Moschus berezovskii & 55.5 & $180-200$ & 175-194 \\
\hline Mber99B $^{3}$ & $15.0 \mu \mathrm{M}$ & $(\mathrm{CA})_{27}$ & Moschus berezovskii & 58 & $270-280$ & 285-311 \\
\hline NVHRT $16^{4}$ & $0.02 \mu \mathrm{M}$ & $\begin{array}{l}(\mathrm{CA})_{5} \mathrm{TA}(\mathrm{CA})_{5} \\
(\mathrm{TG})_{2} \mathrm{CG}(\mathrm{CA})_{19}\end{array}$ & Rangifer tarandus & 57 & $180-200$ & $152-192$ \\
\hline $\mathrm{RT}^{5}{ }^{5}$ & $0.16 \mu \mathrm{M}$ & $(\mathrm{GT})_{22}$ & Rangifer tarandus & 55 & $220-230$ & $222-240$ \\
\hline $\mathrm{RT}^{5} 5^{5}$ & $0.16 \mu \mathrm{M}$ & $(\mathrm{GT})_{22}$ & Rangifer tarandus & 55.5 & $150-160$ & $143-171$ \\
\hline RT06 $^{5}$ & $0.16 \mu \mathrm{M}$ & $(\mathrm{GT})_{23}$ & Rangifer tarandus & 55 & $120-130$ & $105-117$ \\
\hline RT0 $07^{5}$ & $0.16 \mu \mathrm{M}$ & $(\mathrm{GT})_{18}$ & Rangifer tarandus & 55 & $190-200$ & $216-234$ \\
\hline RT095 & $0.16 \mu \mathrm{M}$ & $(\mathrm{GT})_{21}^{18}$ & Rangifer tarandus & 55 & $120-130$ & $116-128$ \\
\hline $\mathrm{RT}^{3} 3^{5}$ & $0.16 \mu \mathrm{M}$ & $(\mathrm{GT})_{13}$ & Rangifer tarandus & 55 & $290-295$ & 293-314 \\
\hline RT30 $0^{5}$ & $0.16 \mu \mathrm{M}$ & $(\mathrm{GT})_{21}$ & Rangifer tarandus & 55.5 & $200-220$ & $190-220$ \\
\hline $\mathrm{T} 156^{6}$ & $0.3 \mu \mathrm{M}$ & TAGA & Cervus elaphus canadensis & 58 & $110-120$ & $134-234$ \\
\hline
\end{tabular}

${ }^{1}$ Gaur et al. (2003), ${ }^{2}$ Xia et al. (2006), ${ }^{3}$ Zou et al. (2005), ${ }^{4}$ Roed and Midthjell (1998), ${ }^{5}$ Wilson et al. (1997), ${ }^{6}$ Jones, et al. (2002). Temperature $\left({ }^{\circ} \mathrm{C}\right)$, annealing temperature standardized for M. americana, M. gouazoubira, M. bororo, M. nana, and M. nemorivaga.

The polymerase chain reaction (PCR) conditions were standardized to a final volume of $15 \mu \mathrm{L}$ containing $10 \mathrm{mM} \mathrm{Taq}$ buffer $(10 \mathrm{mM}$ Tris- $\mathrm{HCl}, \mathrm{pH} 8.4,50 \mathrm{mM} \mathrm{KCl,} 2 \mathrm{mM}$ $\mathrm{MgCl}_{2}$ ), $120 \mu \mathrm{M}$ dNTP, $0.3 \mathrm{U} \mathrm{Taq}$ polymerase, $45 \mathrm{ng}$ genomic DNA and $0.08 \mu \mathrm{M}$ of each primer. The concentration of each primer is described in Table 1. The amplifications for 13 primers (RT01, RT05, RT06, RT07, RT09, RT13, RT30, Mber99B, Mber43B, Mber39B, T156, NVHRT16, CA71) were performed in a T1 Thermocycler under the following conditions: $94^{\circ} \mathrm{C}$ for $5 \mathrm{~min}, 94^{\circ} \mathrm{C}$ for $1 \mathrm{~min}, 49^{\circ}$ to $58^{\circ} \mathrm{C}$ for $1 \mathrm{~min}$ (according to each primer), $72^{\circ} \mathrm{C}$ for $1 \mathrm{~min}$ and $72^{\circ} \mathrm{C}$ for $10 \mathrm{~min}$. The amplification for primer Mber $710 \mathrm{~B}$ was carried out in a gradient thermocycler. Despite the success obtained for the 14 loci, the standardization of PCR conditions for the primer Mber25F was not achieved due to the occurrence of many nonspecific fragments, and therefore, this primer was discarded. The locus Mber39B showed the amplification of a few nonspecific regions, and therefore, excision of the fragment of interest was performed, in order to obtain only the region that was the specific size of the microsatellite described for this primer. To achieve this, the elution and reamplification of the fragment were performed from the electrophoresis of the initial PCR product, on a $2 \%$ low-melting gel. The band of interest was excised, and placed in a tube with $300 \mu \mathrm{L}$ water. This tube was then placed in a water bath at $73^{\circ} \mathrm{C}$ for $20 \mathrm{~min}$. Finally, a new PCR was carried out, using $3 \mu \mathrm{L}$ of the eluted product, obtaining only the fragment of interest, which was confirmed by visualization of this product on a $2 \%$ agarose gel. 
The amplified products of the 14 primers were separated by electrophoresis on a $2 \%$ agarose gel. Next, the PCR products were applied to a $10 \%$ denaturing polyacrylamide gel, stained with ethidium bromide and analyzed. From the visualization of the amplified fragments on agarose and polyacrylamide gels, it was possible to determine whether the size of the amplified product coincided with the size of the microsatellite locus described in the literature for the primer concerned.

The products were purified by the removal of nucleotides with exonucleases. For this, $0.5 \mu \mathrm{L}$ ExoI, $0.5 \mu \mathrm{L}$ shrimp alkaline phosphatase (SAP), $1.0 \mu \mathrm{L}$ SAP buffer, $1.0 \mu \mathrm{L}$ water, and $7 \mu \mathrm{L}$ PCR product were placed in each tube. The solutions were placed in the thermocycler: $37^{\circ} \mathrm{C}$ for $1 \mathrm{~h}, 80^{\circ} \mathrm{C}$ for $10 \mathrm{~min}$ and finally $4^{\circ} \mathrm{C}$ for an undetermined time. Next, the samples were sequenced in the ABI PRISM ${ }^{\circledR} 3100$ Applied Biosystems automatic sequencer. The sequencing reaction was performed with the BI Prism BigDye Terminator Cycle Sequencing Ready Reaction Kit. The sequences obtained were analyzed using the Sequence Scanner V1.0 program, to compare the amplified regions with those deposited in GenBank for the species of origin. This made it possible to confirm that the primers amplified the microsatellite locus of the original species and to see the levels of homology both in the microsatellite region and the flanking regions.

\section{RESULTS}

From the sequencing of a sample of the amplification product of each of the 14 primers, the amplification of the same microsatellite region of the original species for which the primer was developed in the five Brazilian species of the genus Mazama was confirmed.

\section{DISCUSSION}

There have been many studies carried out on the transferability of heterologous primers in various species, including Artiodactyla (Engel et al., 1996), Canidae (Gotelli et al., 1994), Mustelidae (O'Connell et al., 1996), Cetacea (Valsecchi and Amos, 1996), Pinnipedia (Coltman et al., 1996), and Primates (Kayser et al., 1996). According to a study by Barbará et al. (2007), the highest percentage of amplification of polymorphic heterologous markers is observed between species of the same genus, in reptiles, birds, mammals, and invertebrates. Transferability between species of the same family shows less significant results for invertebrates and birds, when compared to mammals and reptiles (over $40 \%$ of successful transfer in mammals, over $25 \%$ in fish, and over $10 \%$ in birds).

Of the 15 primers selected for this study, 14 amplified the region of interest in the five Brazilian species of the genus Mazama. Although the primers selected were not developed for Mazama, but for other species of the same family (Cervidae), transferability was high, much higher than the minimum expected of $40 \%$ (Barbará et al., 2007).

Transferability obtained for $93.3 \%$ of animals is a result that can be considered significant. We attributed this success to the criteria used for selection of markers, which provided us with primers with the potential for use in the study species.

The molecular analysis results indicate that Mazama is a polyphyletic genus and, therefore, not a valid genus (Pitra et al., 2004; Gilbert et al., 2006; Duarte et al., 2008). The red brockets differ from grey brockets by at least 5 million years, which suggests an important molecular difference (Duarte et al., 2008). Even so, the primers showed homology in different species of Mazama, which suggests the conservation of these regions analyzed, making them 
potentially important in studies with other South American deer genera that are closely related to the grey brockets (M. gouazoubira and M. nemorivaga), such as Blastocerus, Ozotoceros and Hippocamelus, or close to the red brockets (M. americana, M. bororo, M. nana), such as Odocoileus (Duarte et al., 2008).

The sequencing of the amplified regions settles any doubt about their constitution and their similarity with the regions described in the original species, guaranteeing that these regions were truly conserved during the cervid evolutionary process. This is the case in both the region of the primer and the microsatellite region itself.

The reason the locus Mber25F did not produce positive results is possibly due to the occurrence of a mutation in the binding site of the primer in the common ancestor of the Brazilian species, since this locus was developed for Moschus berezovskii, a species that displays 13.5 million years of evolutionary divergence with the genus Mazama (Gilbert et al., 2006). However, other primers developed for $M$. berezovskii amplified the microsatellites of Mazama, which demonstrates a high level of conservation of the flanking regions, where the primer sequences are situated.

The description of this panel of primers for studies in Brazilian deer opens an immense field for population studies in these species, some threatened with extinction (IBAMA, 2003). This has the potential to help these endangered populations in both the diagnosis of problems, as well as in making recommendations regarding management for their maintenance.

\section{ACKNOWLEDGMENTS}

Research supported by FAPESP and CNPq. We thank the technicians João Boer and Paulo Tosta for their assistance in the laboratory and Dr. Renato Caparroz for discussions and comments on this study.

\section{REFERENCES}

Abril VV and Duarte JMB (2008). Mazama nana. In: IUCN 2009. IUCN Red List of Threatened Species. Version 2009.2. Available at [http://www.iucnredlist.org]. Accessed February 5, 2010.

Barbará T, Palma-Silva C, Paggi GM, Bered F, et al. (2007). Cross-species transfer of nuclear microsatellite markers: potential and limitations. Mol. Ecol. 16: 3759-3767.

Chesser RK (1983). Isolation by Distance: Relationship to the Management of Genetic Resources. In: Genetics and Conservation: a Reference for Managing Wild Animal and Plant Populations (Schonewald-Cox CM, Chambers SM, MacBryde B and Thomas L, eds.). The Benjamin/Cummings Publishing Company, Menlo Park, 66-77.

Coltman DW, Bowen WD and Wright JM (1996). PCR primers for harbour seal (Phoca vitulina concolour) microsatellites amplify polymorphic loci in other pinniped species. Mol. Ecol. 5: 161-163.

Duarte JMB (2008). Mazama bororo. In: IUCN 2009. IUCN Red List of Threatened Species. Version 2009.2. Available at [http://www.iucnredlist.org]. Accessed February 5, 2010.

Duarte JMB and Merino ML (1997). Taxonomia e Evolução. In: Biologia e Conservação de Cervídeos Sul-Americanos: Blastocerus, Ozotocerus e Mazama (Duarte JMB, ed.). Funep, Jaboticabal, 1-21.

Duarte JM, Gonzalez S and Maldonado JE (2008). The surprising evolutionary history of South American deer. Mol. Phylogenet. Evol. 49: 17-22.

Eisenberg JF and Redford KH (1999). Mammals of the Neotropics: the Central Neotropics. The University of Chicago Press, Chicago.

Engel SR, Linn RA, Taylor JF and Davis SK (1996). Conservation of microsatellite loci across species of Artiodactyls: implications for population studies. J. Mammal. 77: 504-518.

Ferreira ME and Grattapaglia D (1996). Introdução ao Uso de Marcadores RAPD e RFLP em Análise Genética. EMBRAPA - CENARGEN, Brasília. 
FitzSimmons NN, Moritz C and Moore SS (1995). Conservation and dynamics of microsatellite loci over 300 million years of marine turtle evolution. Mol. Biol. Evol. 12: 432-440.

Gaur A, Singh A, Arunabala V, Umapathy G, et al. (2003). Development and characterization of 10 novel microsatellite markers from Chital deer (Cervus axis) and their cross-amplification in other related species. Mol. Ecol. Notes 3: 607-609.

Gilbert C, Ropiquet A and Hassanin A (2006). Mitochondrial and nuclear phylogenies of Cervidae (Mammalia, Ruminantia): Systematics, morphology, and biogeography. Mol. Phylogenet. Evol. 40: 101-117.

Gottelli D, Sillero-Zubiri C, Applebaum GD, Roy MS, et al. (1994). Molecular genetics of the most endangered canid: the Ethiopian wolf Canis simensis. Mol. Ecol. 3: 301-312.

IBAMA (Instituto Brasileiro do Meio Ambiente e dos Recursos Naturais Renováveis) (2003). Available at [http://www. ibama.gov.br]. Accessed June 23, 2003.

Jones KC, Levine K and Banks JD (2002). Characterization of 11 polymorphic tetranucleotide microsatellites for forensic applications in California elk (Cervus elaphus canadensis). Mol. Ecol. Notes 2: 425-427.

Kayser M, Ritter H, Bercovitch F, Mrug M, et al. (1996). Identification of highly polymorphic microsatellites in the rhesus macaque Macaca mulatta by cross-species amplification. Mol. Ecol. 5: 157-159.

Moore KJ, Moser LE, Vogel KP, Waller SS, et al. (1991). Describing and quantifying growth stages of perennial forage grasses. Agron. J. 83: 1073-1077.

Morin PA and Woodruff DS (1992). Paternity Exclusion Using Multiple Hypervariable Microsatellite Loci Amplified from Nuclear DNA of Hair Cells. In: Paternity in Primates: Genetic Tests and Theories (Martin RD, Dixson AF and Wickings EJ, eds.). Karger, Basel, 63-81.

O'Connell M, Wright JM and Farid A (1996). Development of PCR primers for nine polymorphic American mink Mustela vison microsatellite loci. Mol. Ecol. 5: 311-312.

Oliveira EJF (2005). Estrutura Genética Espacial do Cervo-do-Pantanal (Blastocerus dichotomus). Doctoral thesis, Faculdade de Medicina de Ribeirão Preto, USP, Ribeirão Preto.

Pitra C, Fickel J, Meijaard E and Groves PC (2004). Evolution and phylogeny of old world deer. Mol. Phylogenet. Evol. 33: 880-895.

Rafalski JA, Vogel JM, Morgante M, Powell W, et al. (1996). Generating and Using DNA Makers in Plants. In: Analysis of Nonmammalian Genomes: a Practical Guide (Birren B and Lai E, eds.). Academic Press, New York, 75-133.

Roed KH and Midthjell L (1998). Microsatellites in reindeer, Rangifer tarandus, and their use in other cervids. Mol. Ecol. 7: 1773-1776.

Rossi RV (2000). Taxonomia de Mazama rafinesque do Brasil (Artiodactyla, Cervidae). Master's thesis, Instituto de Biociências, USP, São Paulo.

Roy MS, Geffen E, Smith D, Ostrander EA, et al. (1994). Patterns of differentiation and hybridization in North American wolflike canids, revealed by analysis of microsatellite loci. Mol. Biol. Evol. 11: 553-570.

Sambrook J, Fritsch EF and Maniatis T (1989). Molecular Cloning: A Laboratory Manual. 2nd edn. Cold Spring Harbor Laboratory Press, Cold Spring Harbor, 1659.

Schlötterer C and Pemberton J (1994). The Use of Microsatellites for Genetic Analysis of Natural Populations. In: Molecular Ecology and Evolution: Approaches and Applications (Wagner GP, Streit B, Wagner GP and DeSalle R, eds.). Birkhauser Velay, Babel, 203-214.

Schlötterer C, Amos B and Tautz D (1991). Conservation of polymorphic simple sequence loci in cetacean species. Nature 354: 63-65.

Valsecchi E and Amos W (1996). Microsatellite markers for the study of cetacean populations. Mol. Ecol. 5: 151-156.

Wilson GA, Strobeck C, Wu L and Coffin JW (1997). Characterization of microsatellite loci in caribou Rangifer tarandus, and their use in other artiodactyls. Mol. Ecol. 6: 697-699.

Xia S, Zou F and Yue B (2006). Six microsatellite loci in Forest musk deer, Moschus berezovskii. Mol. Ecol. 6: 113-115.

Zane L, Bargelloni L and Patarnello T (2002). Strategies for microsatellite isolation: a review. Mol. Ecol. 11: 1-16.

Zou F, Yue B, Xu L and Zhang Y (2005). Isolation and characterization of microsatellite loci from Forest musk deer (Moschus berezovskii). Zoolog. Sci. 22: 593-598. 